\title{
PISA: czytanie, rozumienie, rozumowanie i - nieporozumienia
}

\section{PISA: reading, reasoning, understanding and - misunderstandings}

\author{
Krzysztof Biedrzycki \\ Uniwersytet Jagielloński, Kraków \\ ORCID: 0000-0002-5110-6986
}

\begin{abstract}
The article is a synthetic presentation of the assumptions and results of the PISA study. The article discuses methodology of assessment, ways of doing it and forms of tasks. Particular attention is paid to the main field from the year 2018, i.e. the understanding of the text being read. Basic concepts related to the text, the situation of the reader, and the act of reading were explained. The following sections discuss the results, taking into account other areas (mathematics, life sciences), historical changes and comparisons with other countries. The results of contextual research were also presented, which give the opportunity to examine the climate of Polish schools, teaching methods, and students' well-being. Finally, a proposal for the interpretation of the results is presented.
\end{abstract}

Key words: PISA, reading literacy, education, school, student, teacher

Streszczenie: Artykuł stanowi syntetyczne przedstawienie założeń i wyników badania PISA. Omówione są metodologia badania, sposób jego przeprowadzania, formy zadań. Szczególną uwagę poświęca się dziedzinie głównej z roku 2018, czyli rozumieniu czytanego tekstu. Zostały wyjaśnione podstawowe pojęcia związane z tekstem, sytuacją czytelnika, aktem lektury. W dalszej części omówiono wyniki, z uwzględnieniem pozostałych dziedzin (matematyka, nauki przyrodnicze), zmian w ujęciu historycznym oraz porównań z innymi krajami. Przedstawione zostały również wyniki badań kontekstowych, które dają możliwość przyjrzenia się klimatowi polskiej szkoły, sposobom nauczania, dobrostanowi uczniów. Na koniec została przedstawiona propozycja interpretacji wyników.

Słowa kluczowe: PISA, czytanie, edukacja, szkoła, uczeń, nauczyciel

3 grudnia 2019 roku ogłoszono wyniki badania PISA 2018. Reakcje mediów były entuzjastyczne. „Gazeta Wyborcza”: „Wielki sukces gimnazjów"1, „Głos Nauczycielski”: „Ogromny sukces polskich gimnazjalistów”2, „Sprawy Nauki”: „Sukces uczniów i nauczycieli”, ,Polska Times”:

${ }^{1}$ https://wyborcza.pl/7,75398,25473589, eksperci-o-swietnych-wynikach-pisa-2018-to-raportzamkniecia.html (dostęp: 13.09.2020).

2 https://glos.pl/e artykuly/pisa-2018-ogromny-sukces-polskich-gimnazjalistow-niestety-gimnazjow-juz-nie-ma (dostęp: 13.09.2020).

${ }^{3}$ http://www.sprawynauki.edu.pl/4264-pisa-2018-sukces-uczniow-i-nauczycieli (dostęp: 13.09.2020). 
„Polscy uczniowie w europejskich czołówce”4, RMF FM: „Sukces polskich

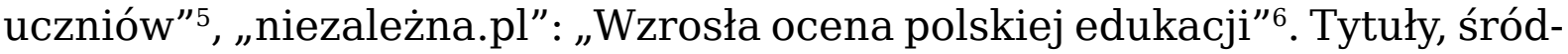
tytuły, nagłówki można mnożyć. Po jakimś czasie pojawiły się jednak i takie tytuły: „Holistic”: „Polscy uczniowie mają sukcesy - ale czy są szczęśliwi?” "Oko-Press”: „Ciemna strona badań PISA 2018. Polski uczeń nieszczęśliwy, przepracowany i niepewny sukcesu"8. Tym razem nie wybrzmieli sceptycy, którzy negują wartość badania, oni bywali głośni po publikowaniu wyników z poprzednich edycji. Rzecz ciekawa, tonacja opinii była podobna niezależnie od opcji politycznej, różne były tylko wyjaśnienia: sukces mógł być zasługą gimnazjów, które wskutek reformy edukacji zostały zlikwidowane, lub sukces jest rezultatem właśnie reformy, lub też jest zasługą samych uczniów, nauczycieli, rodziców, Polski itd., ale nie szkoły. I z drugiej strony: uczniowie są nieszczęśliwi, bo zła jest szkoła, ale zła po reformie lub zła przed reformą (więc teraz się zmieni).

Czemu przywołuję te głosy medialne? Wyniki badania PISA krótko budzą emocje, po czym są zapominane. Publikuje się rankingi, sukces cieszy, niepowodzenia martwią, niekiedy pojawiają się głosy sceptyczne. Jak to jednak bywa $\mathrm{z}$ medialnymi doniesieniami, nie zawsze wiadomo, o czym tak naprawdę mowa. Tabele, liczby, pozycje w porównaniu z innymi krajami - to działa na wyobraźnię. Interpretacje wyników mogą być jednak różne, jak różne są opinie naukowe, polityczne czy światopoglądowe. Żeby jednak rzetelnie potraktować informacje, które można zaczerpnąć z raportów PISA, trzeba wiedzieć, po co prowadzone jest to badanie, w jaki sposób, co ono sprawdza i jak należy rozumieć miejsce w rankingu. Postarajmy się zatem uporządkować wiedzę na ten temat.

\section{O badaniu PISA}

Badanie PISA organizowane jest przez OECD (Organizację Współpracy Gospodarczej i Rozwoju, do której Polska należy od 1996 roku) ${ }^{9}$. Jako cel stawia sobie porównanie poziomu kompetencji niezbędnych w dalszym życiu uczniów z różnych krajów (wszystkich członków OECD oraz kilkudziesięciu innych krajów i regionów), którzy w roku poprzedzającym badanie ukończyli 15 lat. Chodzi o dostarczenie odpowiedzialnym za edukację władzom informacji, które mogą służyć do takiego prowadzenia polityki oświatowej, aby umożliwić młodym ludziom dobry start do dalszej edukacji, aktywności obywatelskiej czy na rynku pracy. Badanie prowadzone jest

4 https://polskatimes.pl/wyniki-badania-pisa-2018-polscy-uczniowie-w-europejskiej-czolowce/ar/ c1-14626385 (dostęp: 13.09.2020).

${ }^{5}$ https://www.rmf24.pl/tylko-w-rmf24/jerzy-lackowski/komentarze/news-sukces-polskich-uczniow-w-badaniach-pisa-2018,nId,3378734 (dostęp: 13.09.2020).

https://niezalezna.pl/300192-uczniowie-lepsi-w-czytaniu-w-naukach-matematycznych-i-przyrodniczych-wzrosla-ocena-polskiej-edukacji (dostęp: 13.09.2020).

https://holistic.news/badanie-pisa-2018-polscy-uczniowie-maja-sukcesy-ale-czy-sa-szczesliwi (dostęp: 13.09.2020).

${ }^{8}$ https://oko.press/ciemna-strona-badan-pisa-2018 (dostęp: 13.09.2020)

${ }^{9}$ Szczegółowe informacje na temat badania można znaleźć w następujących publikacjach: Sitek, Ostrowska 2020 oraz PISA 2018 Database, https://www.oecd.org/pisa/data/2018database (dostęp: 8.10.2020). 
od roku 2000, kolejne edycje mają miejsce co trzy lata, Polska uczestniczy w nim od samego początku.

Trzeba podkreślić, że PISA nie sprawdza stopnia realizacji założonych celów programowych w poszczególnych krajach. Nie przekazuje zatem informacji o erudycji uczniów, o ich wiedzy historycznej czy znajomości faktów z poszczególnych przedmiotów; innymi słowy - abstrahuje od podstaw programowych. Nie mówi wszystkiego o systemie edukacji i osiągnięciach uczniów. Można metaforycznie powiedzieć, że jest to dokładne badanie tomograficzne, ale ono nie pokazuje temperatury ciała, morfologii krwi czy dna oka. Pojawiające się niekiedy zarzuty, iż PISA przedstawia fałszywy obraz szkoły, oparte są na nieporozumieniu: badanie pokazuje tylko wyimek życia szkolnego, a tak właściwie to głównie stopień opanowania konkretnych umiejętności, nie zawsze przecież będący efektem edukacji formalnej.

PISA obejmuje trzy główne dziedziny: rozumienie czytanego tekstu, myślenie matematyczne, rozumowanie w naukach przyrodniczych. Ponadto w niektórych edycjach i krajach, które na to się decydują, prowadzone są dodatkowe badania, np. umiejętności rozwiązywania problemów lub umiejętności finansowe. Oprócz tego uczniowie odpowiadają na pytania kontekstowe dotyczące np. atmosfery szkolnej, ich dobrostanu, planów na przyszłość, czytelnictwa, stosunku do nauki itp.

Dziedziny główne obejmują tzw. literacy, co w języku polskim oddaje się jako alfabetyzację lub piśmienność, co brzmi myląco, bo kojarzy się wyłącznie z umiejętnością czytania i pisania, w dodatku na elementarnym poziomie. Tymczasem chodzi o coś innego. W największym skrócie można powiedzieć, że badaniu podlega zespół umiejętności, które pozwalają na swobodne radzenie sobie $\mathrm{z}$ wyzwaniami intelektualnymi, przed jakimi może stanąć człowiek. Począwszy od odbioru informacji zawartych w tekście przez stosowanie narzędzi matematycznych w porządkowaniu obrazu świata i poruszaniu się $\mathrm{w}$ nim po naukową analizę faktów i weryfikację hipotez. Nie sprawdza się zatem czystej wiedzy (choć w dziedzinie rozumowania w naukach przyrodniczych jest zawarty pewien jej komponent) czy formalnych umiejętności, ale gotowość do ich praktycznego wykorzystywania. Tak więc np. nie pyta się o twierdzenie Pitagorasa, ale tak zostaje sformułowane zadanie, żeby w wyznaczeniu długości lin w latawcu stanowiącym napęd statku to twierdzenie zostało wykorzystane. Podobnie nie zadaje się pytania o związek ginięcia pszczół ze zmniejszeniem populacji ptaków, ale prezentuje się teksty na ten temat i stawia się polecenia wyciągnięcia wniosków dotyczących relacji przyczyn i skutków, analizy danych czy stawiania i uzasadniania hipotez.

W badaniu biorą udział osoby, które w roku je poprzedzającym ukończyły 15 lat (tak więc w roku 2018 wzięli udział uczniowie urodzeni w 2002 roku). Dokonuje się losowania według precyzyjnie opracowanego schematu doboru próby (Sitek, Ostrowska 2020, 19-38). W ostatniej edycji w Polsce w badaniu wzięło udział 5653 piętnastolatków. Wyniki opracowuje się dla 
grup, nie dla poszczególnych uczniów, stąd podziały według państw, płci, miejsca zamieszkania, typu szkoły lub zamożności rodzin uczniów. Odsetki uczniów osiągających wyniki punktowe dzieli się ponadto według poziomów umiejętności. Poziomy te zostały wyznaczone probabilistycznie na podstawie oszacowanej trudności zadań.

Zadania tak są opracowane, żeby wyniki ich wykonania mogły być porównywalne w dwóch przekrojach. Po pierwsze w przekroju geograficznym - żeby można było wprowadzić porównanie między krajami. Po drugie w przekroju czasowym od początku badania w 2000 roku. Ten wymóg sprawia, że zadania są długo przygotowywane i standaryzowane. Trzeba możliwie zminimalizować wszelkie stanowiące przeszkody uwarunkowania kulturowe. Zarazem jednak w ciągu lat zmienia się kontekst cywilizacyjny, zwłaszcza technologiczny, a także nieustannie wzbogacana jest wiedza o mechanizmach uczenia się, w tym o sposobach sprawdzania umiejętności. Dlatego opracowywane są nowe zadania. Ażeby zachować porównywalność w ciągu lat, zachowuje się jednak część zadań (tzw. zadania kotwiczące). Ponieważ większość zadań, zwłaszcza zadania kotwiczące, ale też nowe zadania, nie jest ujawnianych, bo będą wykorzystywane w kolejnych edycjach badania, tworzy się wokół nich aura tajemniczości. Niektórzy oponenci zarzucają, że PISA jest wyrazem trywialnej testomanii i w gruncie rzeczy niewiele sprawdza. Wystarczy jednak zapoznać się z kilkunastoma ujawnionymi dotychczas wiązkami zadań, żeby zobaczyć, na czym one polegają (Sitek, Ostrowska 2020, 88-127, 162-171, 202-206). Owszem, są zadania z niskich poziomów umiejętności, które wydają się bardzo proste (chodzi o sprawdzenie umiejętności uczniów słabo sobie radzących w objętych badaniem dziedzinach), ale zadania ze średnich i wysokich poziomów wymagają sprawnego, a niekiedy głębokiego myślenia. To nie są testy, tak jak postrzega się je w potocznej opinii. Wiązki zadań w badaniu PISA oparte są na scenariuszach przewidujących procedury intelektualne, które powinien wykonać uczeń, żeby dojść do właściwej odpowiedzi. Od prostych czynności kognitywnych po pogłębione interpretacje tekstów, faktów czy wyników obliczeń.

\section{Rozumienie czytanego tekstu}

W 2018 roku główną dziedziną badania było rozumienie czytanego tekstu. W wersji angielskiej określane jest jako reading literacy, co jednak trudno bez spłycania terminologii oddać po polsku. Chodzi tu mianowicie o sprawdzenie biegłości w zakresie działań związanych z czytaniem na różnych poziomach, od prostego dekodowania po skomplikowane operacje związane $\mathrm{z}$ rozumieniem tekstu. Przyjęta jest następująca definicja: „rozumienie czytanego tekstu to proces obejmujący odczytania znaczeń, wykorzystanie tekstu, ocenę, refleksję i takie zaangażowanie w lekturę, by osiągnąć zamierzony cel, pogłębić wiedzę, 
zwiększyć własny potencjał intelektualny i uczestniczyć w życiu społecznym" (Sitek, Ostrowska 2020, 39) ${ }^{10}$.

Tekstem jest tu każde użycie języka w formie graficznej, uwzględniające wszakże również takie elementy, jak diagramy, grafiki czy mapy, ważne, żeby był w nich obecny jakiś element językowy. Od 2015 roku badanie jest przeprowadzane w formie elektronicznej. W ostatniej edycji (PISA 2018 Database $)^{11}$ zostały dodane teksty możliwe do czytania tylko na nośniku cyfrowym (hiperteksty zawierające linki do różnych stron internetowych ), były jednak obecne też teksty znane z dawnych edycji, które wtedy funkcjonowały $\mathrm{w}$ formie drukowanej. Celem było wprowadzenie różnorodności analizowanych wypowiedzi. Różnorodność dotyczyła nie tylko strony technicznej, ale też formy. Były zatem przedstawione teksty pojedyncze (jeden autor, tytuł) lub zwielokrotnione (wielu autorów, różne daty publikacji, kilka tytułów - taki charakter mają np. teksty w Internecie). Są teksty ciągłe (zwarta struktura, logika wywodu, forma językowa) i nieciągłe (informacje przekazywane za pomocą słów łączą się z wykresami, tabelami, ilustracjami). Inne kryterium pozwala na podział na teksty statyczne (tradycyjne, wyłącznie do czytania) i dynamiczne (charakterystyczne dla Internetu, wymagające aktywności odbiorcy, który łączy się z wieloma stronami, żeby stworzyć własny hipertekst). Nie trzeba dodawać, że teksty reprezentują rozmaite gatunki, od utworów literackich po blogi i fora internetowe. Tak więc mamy teksty narracyjne, informacyjne, argumentacyjne, a także instrukcje i umowy.

Po jednej stronie jest tekst. Ale po drugiej - znajduje się czytelnik. $\mathrm{W}$ badaniu brane są pod uwagę różne sytuacje czytelnika. One są ważne, gdyż wpływają na akt lektury. Przede wszystkim trzeba dostrzec rolę zaangażowania odbiorcy, jego świadomości tego, po co czyta. Może to być sytuacja osobista, np. czytanie dla przyjemności lub dla pozyskania jakichś informacji. Może być sytuacja publiczna obejmująca udział w życiu społecznym, od czytania wiadomości po zaangażowanie w jakieś akcje, oficjalną korespondencję czy lekturę dokumentów. Sytuacja zawodowa dla piętnastolatków jest jeszcze obca, ale w zadaniach pojawiają ogłoszenia o pracę, instrukcje, raporty - z takimi formami tekstów uczniowie spotkają się już w nieodległej przyszłości. Najczęstsza, i w trakcie badania najbardziej oczywista, jest sytuacja edukacyjna - czytanie zadanych tekstów w celu nauczenia się czegoś. Oczywiście te sytuacje nakładają się na siebie i nie chodzi o ich separowanie, ale trzeba je brać pod uwagę, gdy się bada odbiór tekstów.

Proces odbioru tekstu badany jest w następujący sposób:

${ }_{10}$ Do rozdziału pt. Rozumienie czytanego tekstu z cytowanego dokumentu odnoszą się informacje zawarte w dalszych partiach niniejszego artykułu. Warto również zapoznać się pełną wersją założeń teoretycznych badania: PISA 2018. Assessment and Analytical Framework, https://www.oecd-ilibrary.org/docserver/b25efab8-en.pdf?expires $=1601304757$ \&id=id\&accname = guest\&checksu$\underline{m=B 9381 E E D 5 E 1 B 07253 E E B 8 F F 0 D 93 F B 7 A A}$ (dostęp: 8.10.2020).

${ }^{11}$ https://www.oecd.org/pisa/data/2018database (dostęp: 8.10.2020). 
1. W pierwszym etapie wszyscy zdający są poddawani testowi płynnego czytania, w ten sposób zostają wyłączone osoby mające problem z odbiorem tekstu na elementarnym poziomie. Badanie komputerowe pozwala nie tylko stwierdzić, czy badany rozumie przeczytane zdanie, ale jak szybko przeprowadza proces dekodowania. W Polsce niemal wszyscy uczniowie przeszli ten etap, co wcale nie jest oczywiste, bo w wielu krajach zauważalny odsetek uczniów nie wykazał się elementarną umiejętnością płynnego czytania.

2. Rozumienie czytanego tekstu zaczyna się od wyszukiwania informacji w nim zawartej (tę umiejętność sprawdza 13\% zadań).

3. W przypadku tekstów zwielokrotnionych trzeba jeszcze wyszukać i właściwie dobrać teksty zawierające potrzebne informacje $(8 \%$ zadań).

4. Kolejnym etapem jest podanie dosłownego znaczenia poszczególnych fragmentów, zdań, akapitów (22\% zadań).

5. Potem następuje integracja sensów, łączenie ich, dostrzeganie zależności między nimi, czego konsekwencją jest odczytanie przekazu zawartego w całym tekście (26\% zadań).

6. Dalszym etapem jest ocena jakości i wiarygodności tekstu, a także powiązana z tym refleksja nad treścią i formą przekazu (18\% zadań).

7. W przypadku tekstów zwielokrotnionych ostatnim etapem jest dostrzeżenie konfliktu racji w różnych wypowiedziach i znalezienie rozwiązania ( $7 \%$ zadań).

Zadania mają zróżnicowany charakter. Dominują zadania zamknięte (64\%) o rozmaitej formie. W zadaniach otwartych ocenie nie podlega sposób sformułowania odpowiedzi (nie jest badana umiejętność pisania) ani wypowiedziana opinia. Oceniane jest zrozumienie tekstu (w tym zrozumienie polecenia) i argumentacja służąca uzasadnieniu przedstawionego zdania. Kryteria akceptacji odpowiedzi są wypracowywane w toku pilotażu i są jednakowe we wszystkich krajach. Podaje się pozytywne przykłady, ale nie po to, by sprawdzający trzymali się ich bezrefleksyjnie, ale żeby pokazać, w jakich kierunkach może podążać myśl ucznia. Najważniejsze jest jednak wyznaczenie granicy między odpowiedzią prawidłową i nieprawidłową.

Każde zadanie ma przypisany cel, to znaczy, którą umiejętność sprawdza, a także jaki poziom trudności reprezentuje. Po zebraniu wyników można przypisać uczniów do poszczególnych poziomów umiejętności. W przypadku rozumienia czytanego tekstu mamy siedem poziomów, przy czym dwa najniższe opisywane są jako 1 a i 1 b, gdyż poniżej 2 poziomu mamy do czynienia z bardzo słabym opanowaniem umiejętności, właściwie z funkcjonalnym analfabetyzmem, gdy znajomość reguł pisma nie wystarcza, żeby zrozumieć zawarty w tekście przekaz.

- Na poziomie 1 b uczeń znajduje w tekście tylko bardzo proste informacje. 
- Na poziomie $1 \mathrm{a}$ w nieskomplikowanym tekście uczeń dostrzega nieobcą mu treść.

- Na poziomie 2 uczeń odczytuje główną myśl tekstu, dostrzega relacje między informacjami.

- Na poziomie 3 uczeń wyszukuje w tekście różne informacje (nie zawsze wyeksponowane), rozumie sens kluczowych słów i zdań, porównuje poglądy i postawy, podejmuje refleksję nad argumentacją zawartą w tekście.

- Na poziomie 4 uczeń potrafi wyszukać informacje zawarte głęboko w tekście, interpretuje niejednoznaczności i niuanse, wykorzystuje swoją wiedzę do oceny tekstu.

- Na poziomie 5 uczeń rozumie zarówno całość, jak fragmenty tekstu, dokonuje krytycznej oceny tekstu, ocenia wagę zawartych w nim informacji.

- Na poziomie 6 uczeń formułuje przemyślaną interpretację tekstu, dokonuje jego precyzyjnej analizy, stawia samodzielną hipotezę w ocenie tekstu lub grupy tekstów, wykorzystuje rozmaite kryteria, zestawia informacje zawarte w co najmniej dwóch tekstach.

Analiza wyników badania zyskuje walor dopiero, gdy się ma świadomość, z jakimi zadaniami mierzyli się uczniowie i co te zadania sprawdzały. A i to nie jest pełna wiedza. Bo obok badania umiejętności sprawdzane jest wiele czynników kontekstowych, o które uczniowie są pytani w ankietach. Wyniki trzeba zatem konfrontować z tym, czego dowiadujemy się o szkole, o domach uczniów, o ich postawach, o nauczycielach itd.

\section{Wyniki badania PISA}

Ministra, dziennikarzy i ekspertów najbardziej zelektryzowały wyniki badania. Zanim je przypomnimy, zróbmy jedno zastrzeżenie. Ranking nie jest termometrem precyzyjnie mierzącym stan umiejętności uczniów. Punktacja wyznaczona jest za pomocą skomplikowanych procedur statystycznych. Tak naprawdę zatem zamiast mówić o konkretnych miejscach w tabeli wyników, należy wskazywać grupy krajów, których wyniki nie różnią się statystycznie w istotny sposób. To zastrzeżenie jest ważne, żeby uniknąć nieporozumień. Dla uproszczenia będziemy się jednak również posługiwali punktacją przedstawioną przez OECD i rankingiem, ale uwzględnimy powyższe zastrzeżenie.

Polscy piętnastolatkowie w 2018 roku w pomiarze rozumienia czytanego tekstu uzyskali średnio 512 punktów. W rankingu to dziesiąta pozycja w świecie na 79 krajów i regionów. W Europie jest to czwarte miejsce, po Estonii, Finlandii i Irlandii (dodajmy, że pierwsze miejsca na świecie zajęły regiony Chin oraz Singapur i Korea Południowa, wysoką lokatę uzyskała też Kanada). Istotniejsze jest jednak wskazanie krajów, których wynik nie jest w istotny sposób różny od wyniku Polski, to: Irlandia, Korea Południowa, 
Szwecja i Nowa Zelandia. Okazuje się zatem, że wyraźnie wyższe wyniki uzyskały tylko dwa kraje europejskie i Chiny oraz Singapur (zresztą też zamieszkiwany w większości przez Chińczyków). Radość ministra i entuzjastyczne nagłówki prasowe miały więc swoje uzasadnienie.

Podobnie wysokie wyniki uzyskali polscy uczniowie w pozostałych dwóch dziedzinach. Z matematyki było to 516 punktów. Co oznaczało dziesiątą pozycję w świecie i trzecią w Europie, osiągnięcia porównywalne statystycznie zyskali uczniowie w Holandii, Szwajcarii i Kanadzie. W naukach przyrodniczych średni wynik wyniósł 511 punktów, dawało to jedenastą pozycję w świecie i trzecią w Europie. Nie różnił się on w istotny sposób statystycznie od wyników uczniów w Hongkongu, Tajwanie, Nowej Zelandii, Słowenii i Wielkiej Brytanii.

Tak wyglądali polscy piętnastolatkowie w porównaniu z ich kolegami na całym świecie. Znacznie ciekawsze są jednak różne inne wymiary tych wyników. Przede wszystkim w ujęciu diachronicznym. Przypominam: pierwsze badanie PISA zostało przeprowadzone w roku 2000. Polscy uczniowie uzyskali wówczas z rozumienia czytanego tekstu średnio 479 punktów przy wyniku dla krajów OECD 494 punkty. W roku 2003 Polacy osiągnęli już 497 punkty (OECD 494), w 2006 - 508 punktów (OECD 485), w 2009 - 500 punktów (OECD 491), w 2012 - 518 punktów (OECD 493), w 2015 - 506 punktów (OECD 490). Jak widać, wyniki polskich uczniów wyraźnie wzrosły od pierwszej edycji, ulegały różnym wahaniom, ale od 2006 roku nigdy już nie spadły poniżej 500 punktów. Podobnie wyniki wzrosły w pozostałych dziedzinach. W matematyce z 490 w 2003 roku (kiedy matematyka po raz pierwszy była główną dziedziną) do 518 w 2012 i 516 w 2018 (średnia OECD w tym czasie spadła z 499 do 489). W naukach przyrodniczych w 2006 roku (pierwszy raz jako badanie główne) polscy uczniowie zyskali 498 punktów przy średniej OECD 495, w ostatniej edycji - przypomnijmy - 511 punktów przy średniej OECD 489.

Można na to spojrzeć jeszcze inaczej. W 2000 roku w dziedzinie rozumienia czytanego tekstu wynik statystycznie istotnie lepszy uzyskało 16 krajów na świecie, w tym 10 w Europie, w 2018 - 7 na świecie, w tym 2 w Europie; w 2003 roku wynik statystycznie istotnie lepszy w dziedzinie rozumowania matematycznego uzyskało 21 krajów na świecie, w tym 12 w Europie, w 2018 - 8 krajów na świecie, w tym 1 (słownie: jeden) w Europie; w 2006 wynik statystycznie istotnie lepszy od Polski w dziedzinie rozumowania w naukach przyrodniczych uzyskało 20 krajów na świecie i 10 krajów w Europie, w 2018 - 8 krajów na świecie i 2 kraje w Europie.

Spójrzmy na inny przekrój, według poziomów umiejętności. W 2000 roku w dziedzinie rozumienia czytanego tekstu $24 \%$ polskich uczniów osiągnęło wynik poniżej drugiego poziomu (a więc na granicy funkcjonalnego analfabetyzmu), w 2018 roku było to niespełna 15\% (zbliżony odsetek utrzymuje się od roku 2003). W Europie mniej uczniów uzyskujących najsłabsze wyniki jest tylko w Estonii, Irlandii oraz Finlandii, średnio w krajach OECD 
jest to $23 \%$ piętnastolatków. Podobne odsetki uczniów o najniższych wynikach dotyczą matematyki (15\% w Polsce, 23\% w krajach OECD), tutaj tylko dwa kraje europejskie mają niższy odsetek - Estonia i Dania. Jeśli chodzi o nauki przyrodnicze, to tylko $14 \%$ uczniów w Polsce nie osiągnęło drugiego poziomu, w Europie było ich mniej w Estonii i Finlandii.

Z kolei wzrósł odsetek piętnastolatków uzyskujących wyniki na najwyższych poziomach (piątym i szóstym). W dziedzinie rozumienia czytanego tekstu w 2018 roku było to 12\% (w krajach OECD średnio 8\%), w Europie więcej uczniów osiągało te poziomy tylko w Finlandii, Estonii i Szwecji. W 2000 roku mieliśmy jedynie 6\% takich uczniów, ale już od 2006 z pewnymi wahaniami utrzymuje się ten wysoki odsetek. W matematyce mieliśmy w ostatniej edycji 16\% piętnastolatków na najwyższych poziomach (OECD $10 \%)$, lepsza była tylko Holandia. W naukach przyrodniczych było to $9 \%$ (odsetek ten jest mniej więcej stabilny od początku prowadzenia badania), w Europie więcej uczniów osiąga najwyższe poziomy w Finlandii, Estonii, Holandii, Niemczech i Wielkiej Brytanii.

$6,7 \%$ polskich uczniów nie osiągnęło drugiego poziomu w żadnej dziedzinie, ale 3,5\% tylko $\mathrm{w}$ dziedzinie rozumienia czytanego tekstu. Z kolei najwyższe wyniki w każdej dziedzinie uzyskało 5,3\% piętnastolatków, podczas gdy $3 \%$ tylko w rozumieniu czytanego tekstu. To ciekawe dopełnienie danych, bo pokazuje skalę niepowodzeń i niekwestionowanych sukcesów ze wszystkich przedmiotów, ale też odsetek osób, które albo wyjątkowo sobie nie radzą z czytaniem, albo właśnie tylko z czytaniem radzą sobie nadzwyczaj dobrze.

Na całym świecie wyższe wyniki z czytania uzyskują dziewczęta, nie ma wyjątków. Na tle Europy Polska jawi się najzupełniej przeciętnie (w środku skali), jeśli chodzi o różnice wyników między dziewczętami i chłopcami. W naszym kraju co piąty piętnastolatek nie osiągnął drugiego poziomu umiejętności i tylko co dziesiąta piętnastolatka. Z kolei najwyższe wyniki zyskało 14,8\% dziewcząt i 9,6\% chłopców.

Operacje wykonywane przez uczniów skupiają się w trzech głównych obszarach: odnajdywania informacji, rozumienia całości przekazu, a także oceny tekstu i refleksji wokół niego. Polscy piętnastolatkowie w każdym z tych obszarów uzyskiwali podobne wyniki, co wcale nie jest oczywiste. Na przykład w Estonii i Finlandii ocena i refleksja wypadały słabiej, z kolei w regionach chińskich właśnie ten obszar okazywał się lepiej opanowany przez uczniów. Zapewne dużo zależało od tego, jak akcenty są rozłożone w dydaktyce w poszczególnych krajach, a to z kolei zależne jest od tradycji i czynników kulturowych. Równowaga wszystkich trzech grup umiejętności u polskich uczniów może zaskakiwać, ale może jest to właśnie specyfika dydaktyki nauczania języka polskiego. Warto by się temu przyjrzeć w pogłębionych badaniach.

Podobna równowaga wystąpiła w lekturze różnego rodzaju tekstów: pojedynczych i zwielokrotnionych. To też nie jest oczywiste, bo w wielu 
krajach o wysokich wynikach, np. w Estonii, Szwecji czy Wielkiej Brytanii uczniowie lepiej radzili sobie z tekstami zwielokrotnionymi, czyli najczęściej tekstami internetowymi. Równowaga w polskiej szkole pewnie wynika $\mathrm{z}$ wciąż tradycyjnego nastawienia na lekturę tekstu drukowanego, najczęściej literackiego.

\section{Konteksty: dom, szkoła, czytelnictwo}

Wyżej mowa była o wynikach. PISA przynosi jednak wiele informacji o kontekście, w jakim odbywa się zdobywanie umiejętności rozumienia czytanego tekstu. Najpierw dom. Polscy uczniowie deklarują, że w zasadzie mają dobre warunki nauki, 98\% ma do dyspozycji biurko, 96\% ma w domu komputer (co jest szczególnie ważne w kontekście zdalnego nauczania), 94\% dysponuje potrzebnymi do nauki książkami, zwłaszcza słownikami (w tym $72 \%$ posiada literaturę klasyczną, ale tylko $46 \%$ jakieś tomiki poezji). Zasobność bibliotek domowych jest zróżnicowana: $12 \%$ ma w domach mniej niż 10 książek (według badań Zofii Zasackiej w 11\% domów nie ma w ogóle żadnych książek (Zasacka 2019), ale 17\% posiada od 101 do 200 książek, $14 \%$ - od 201 do 500, a 8\% powyżej 500 pozycji. Oczywiście nie wiemy, czy biurko nie jest dzielone z rodzeństwem, czy w domu jest jeden komputer dla wszystkich i nic nie wiemy o jego jakości, nie jesteśmy też pewni, co dokładnie zawierają księgozbiory. Wydaje się jednak, że minimum niezbędnych warunków do nauki polscy uczniowie mają. Trzeba przy tym podkreślić, że w badaniach empirycznych zauważalna jest wyraźna korelacja między zasobnością bibliotek domowych i warunkami nauki a wynikami. Nie inaczej w badaniu PISA. Im wyższy status społeczno-ekonomiczny, wyższy poziom wykształcenia rodziców, większe miasto, w którym mieszkają - a z tym się łączą wskazane wyżej warunki - tym lepsze wyniki uczniów. Nie zawsze jednak ta korelacja bywa tak prosta, bo na przykład uczniowie z krajów, gdzie domowe biblioteki bywają bardzo zasobne (Norwegia, Luksemburg, Grecja, Węgry), osiągają dosyć przeciętne wyniki w dziedzinie rozumienia czytanego tekstu.

Ważny jest stosunek do czytania. Można nań spojrzeć z różnych stron. $35 \%$ młodych Polaków twierdzi, że w ogóle nie czyta dla przyjemności, 22\% zdecydowanie nie lubi czytania, 40\% czyta tylko, gdy musi, $46 \%$ w lekturze szuka wyłącznie informacji, 34\% czyta książki rzadko lub nie czyta ich w ogóle. To pesymistyczne dane. Odwróćmy jednak perspektywę. Najpierw spójrzmy na problem od strony czasu. Znajdziemy wówczas zaskakujące rzeczy: otóż między 2009 a 2018 rokiem odsetek uczniów nielubiących czytania zmalał: z 29\% do 22\%. Zmalała też liczba piętnastolatków uważających, że czytanie to strata czasu - z 11\% w 2009 do 9\% w 2018. To o tyle znamienne, że w innych krajach (bez mała na całym świecie) oba wskaźniki w tym czasie wzrosły. Przyjmijmy zatem inny przekrój, geograficzny. W porównaniu z innymi krajami biorącymi udział w badaniu PISA polscy 
uczniowie nie należą do tych, którzy najmniej lubią czytać. Jeśli u nas $40 \%$ piętnastolatków czyta tylko wtedy, gdy musi, to średnia OECD wynosi około 50\%, w Finlandii odsetek ten wynosi właśnie 50\%, w Estonii 44\%, a w Norwegii i Belgii po 57\%. W krajach OECD średnio 40\% piętnastolatków w ogóle nie czyta żadnych książek, w samej Finlandii, którą traktujemy jako niedościgły wzorzec, jest to odsetek $44 \%$.

Patrzyliśmy na stosunek do czytania od strony negatywnej (nie lubią, nie czytają itd.). Spójrzmy od strony pozytywnej. Otóż 75\% uczniów odrzuca pogląd o tym, że czytanie to strata czasu, a więc lektura jest dla nich cennym aktem kulturowym, może sami nie zawsze ją lubią, ale doceniają jej wagę. $41 \%$ badanych w Polsce uważa czytanie za jedno ze swoich ulubionych zajęć (w 2009 roku było to 36\%). 40\% czyta z własnej woli (nie tylko, gdy jest to zadane w szkole). Więcej niż godzinę dziennie czyta $27 \%$ uczniów, w tym $10 \%$ nawet więcej niż dwie godziny dziennie - to jeden z najwyższych wskaźników w Europie. 51\% uczniów cieszy się, gdy dostaje książkę, $45 \%$ lubi zaglądać do księgarni. Być może są to deklaracje na wyrost, jest jednak znaczące, że takie postawy uznaje się za wartościowe, skoro sobie samemu się je przypisuje.

Co zatem stoi na przeszkodzie w czytaniu, skoro stosunek do tej aktywności jest dosyć pozytywny (a na tle światowym wyraźnie pozytywny)? Po części biegłość: 37\% uczniów przyznaje, że ma trudności w dokończeniu książki, 39\% twierdzi, że nie może siedzieć bez ruchu dłużej niż 5 minut. 44\% uważa siebie za „złych czytelników”, choć z kolei 80\% sądzi, że potrafi czytać płynnie (co zresztą potwierdza badanie), a zatem niska samoocena łączy się w mniejszym stopniu z brakiem umiejętności, w większym z nastawieniem emocjonalnym. Istnieją jednak przeszkody kulturowe. Chłopcy nie tylko osiągają niższe wyniki w badaniu, ale też deklarują, że mniej czytają, nie lubią czytać i nie mogą długo wytrzymać przy lekturze $(44 \%$ z nich tak deklaruje, podczas gdy tylko $32 \%$ dziewcząt). Przy czym to nie jest tylko kwestia emocji, umiejętności czy fizjologii, ale też powielanie wzorców społecznych. Chłopcy nie mają z kim rozmawiać o książkach (66\%), podczas gdy wielu z nich chętnie słucha, gdy ktoś mówi o literaturze (44\%), a zatem niektórzy może by czytali i rozmawiali o lekturach, ale nie mają z kim. W przypadku dziewcząt nie ma takiej różnicy, zarówno rodzice, jak koleżanki chętnie z nimi rozmawiają o przeczytanych utworach. Tak więc niechęć do książek wielu chłopców powiela jako płciowy stereotyp wdrukowywany w ich świadomość przez społeczeństwo. Dodajmy, że do lektury zmusza ich lub zachęca szkoła, a w praktyce najczęściej nauczycielka, czyli kobieta. Dlatego oni postrzegają czytanie jako aktywność nie przystającą do męskiego wzorca osobowego. Inna przeszkoda kulturowa ma charakter społeczny, na co wskazywaliśmy wyżej - im niższy kapitał społeczno-ekonomiczny, tym mniejsza zasobność bibliotek, mniej pozytywny stosunek do czytania, a w konsekwencji gorsze radzenie sobie z rozumieniem tekstu. 
Jakie strategie służące zrozumieniu tekstu preferują uczniowie? Najwyżej cenione są podkreślanie ważnych części tekstu i streszczanie tekstu własnymi słowami. To strategie uznawane za skuteczne przez uczniów osiągających wysokie wyniki, a zatem - rzeczywiście skuteczne. Koncentrowanie się na tych częściach tekstu, które jest łatwo zrozumieć, i omawianie części tekstu z innymi osobami są chętniej wybierane przez uczniów przeciętnych. Uczniowie słabi nie cenią żadnej strategii.

Co polscy uczniowie czytają z własnej woli? Może zacznijmy od drugiej strony - nigdy lub prawie nigdy komiksów nie czyta $61 \%$ z nich, czasopism $34 \%$, literatury faktu $32 \%$, gazet i powieści $29 \%$. Z tego ostatniego wynika, że z kolei $71 \%$ młodych ludzi przynajmniej kilka razy w roku sięga po powieści i gazety. Natomiast $24 \%$ czyta powieści dosyć często (co najmniej kilka razy w miesiącu), a 9\% kilka razy w tygodniu. Jeszcze chętniej czytane są gazety, co skądinąd jest polską specyfiką, ten wskaźnik powtarza się w różnych badaniach. 35\% piętnastolatków czyta książki wyłącznie w formie drukowanej, 16\% zarówno w postaci drukowanej, jak cyfrowej, ale kolejne $16 \%$ tylko na urządzeniach cyfrowych. To sygnał, że następuje duża zmiana w nawykach czytelniczych związana z technologią.

Oczywiście pomiędzy 2009 a 2018 rokiem niepomiernie wzrosła rola nośników elektronicznych. 82\% młodych ludzi codziennie korzysta z mediów społecznościowych (w 2009 było to 62\%). Coraz więcej z nich szuka informacji w Internecie (50\% codziennie). Jedynie spadła popularność poczty elektronicznej: 29\% piętnastolatków w Polsce nigdy lub prawie nigdy z niej nie korzysta (w 2009 było to 16\%), a codziennie zagląda do niej tylko $7 \% \mathrm{z}$ nich.

W ankiecie uczniowie mogli się odnieść również do lekcji języka polskiego. Jaka wizja szkoły, nauczycieli i tych lekcji wyłania się z opinii uczniów? Tylko 10\% uczniów narzekało na brak dyscypliny na lekcjach języka polskiego, a z kolei $25 \%$ twierdziło, że nigdy nie ma nieporządku i hałasu. Pomiędzy tymi odpowiedziami sytuuje się „czasami”. Można powiedzieć, że dyscyplina nie była problemem. Natomiast zadziwia coś innego. Uczniowie... nie słuchali tego, co nauczyciele mieli im do powiedzenia na lekcji. Tylko 25\% odpowiadało, że słuchało na większości lekcji, niespełna $50 \%$ na niektórych lekcjach, a $17 \%$ nigdy nie słuchało nauczyciela. Co to oznacza? Czy lekcje były mało ciekawe, czy też słaby był kontakt między nauczycielem a uczniem? Jeśli uczniowie nie słuchają, to jakie korzyści wynoszą z lekcji? Z drugiej strony $60 \%$ uczniów uważało, że nauczyciele na większości lekcji wykazywali zainteresowanie ich postępami i byli gotowi, żeby im pomóc. Przy czym przeważnie były to opinie uczniów przeciętnych. Ci wybitni i słabi narzekali, że nie mogli liczyć na swoich nauczycieli. $22 \%$ piętnastolatków twierdziło, że nauczyciele nawet nie próbowali dostosowywać lekcji do możliwości uczniów, tylko 15\% z nich dostrzegało elastyczność u nauczycieli. Również 15\% uważało, iż nauczyciele budowali ich wiarę $\mathrm{w}$ możliwości związane $\mathrm{z}$ umiejętnościami kształtowanymi 
na lekcjach języka polskiego, podczas gdy $30 \%$ się z tym nie zgadzało. Aż $28 \%$ uczniów stwierdziło, że nauczyciele nigdy lub prawie nigdy nie wskazywali na ich mocne strony, a $40 \%$ doświadczało tego rzadko. 52\% nigdy lub prawie nigdy nie słyszało, co i jak może poprawić. $66 \%$ uczniów odczuwało, że nauczyciele nie szanują ich poglądów, 54\% nie mogło się otwarcie nie zgadzać ze zdaniem nauczyciela. Ponad $30 \%$ postrzegało nauczycieli jako nielubiących swojej pracy, $40 \%$ nie widziało w nich radości z uczenia, połowa nie dostrzegała entuzjazmu. Od razu zwróćmy uwagę na kontekst badania: było przeprowadzone $\mathrm{w}$ gimnazjach $\mathrm{w}$ stanie likwidacji. Czy ta surowa ocena nauczycieli była rezultatem niechęci uczniów wynikającej ze stanu niepewności, co dalej z ich edukacją, czy też rzeczywiście nauczyciele $\mathrm{w}$ wygaszanych gimnazjach wykazywali się opisywanymi tu postawami? Może być jednak i tak, że jest to po prostu portret polskiego nauczyciela. Czy sprawiedliwy?

Z drugiej jednak strony według uczniów nauczyciele wyznaczali jasne cele lekcji (69\%). Nauczyciele przeważnie zachęcali uczniów do wyrażania swojego zdania, brania udziału w dyskusjach, aktywnego uczestnictwa w lekcjach. 90\% prowadziło kontrolowaną interpretację tekstu w postaci zadawania pytań. Również prawie 90\% wprowadzało na lekcje charakterystykę postaci. $80 \%$ uczniów mogło wydawać opinie o lekturze. Ale już streszczenia pisało tylko $60 \%$ z nich. Również $60 \%$ miało za zadanie napisać samodzielną pracę związaną z lekturą (co jednak oznacza, że $40 \%$ nauczycieli takich prac nie zadawało).

Na lekcjach języka polskiego dominuje literatura piękna. Spośród krajów europejskich podobna praktyka widoczna jest właściwie tylko w Niemczech. Tylko co trzeci uczeń zapamiętał, że w ciągu poprzedzającego badanie miesiąca więcej niż jeden raz na lekcji pojawił się tekst nieliteracki. Rzadko na lekcjach języka polskiego nauczyciele wykorzystywali media elektroniczne, aż 56\% uczniów twierdziło, że nigdy na języku polskim nie spotkali się z nowoczesną technologią. Skądinąd dotyczyło to nie tylko polonistów, ale też matematyków, a także nauczycieli innych przedmiotów.

Spośród umiejętności praktycznych uczniowie na lekcjach języka polskiego mogli się nauczyć głównie postaw związanych z komunikacją (61\% twierdzi, że nauczyło się komunikować z ludźmi z różnych środowisk), prowadzeniem sporu, rozstrzyganiem konfliktów (63\% nauczyło się tego w szkole). 90\% z nich deklarowało, że z uwagą słucha argumentów uczestników sporu (dyskusji), stara się patrzeć na racje obu stron. Również zyskali oni umiejętność bezpiecznego zachowania w sieci i odpowiedzialności za wyrażane treści.

Z kolei inne praktyczne umiejętności zostały przez szkołę zaniedbane, np. tylko 56\% uczniów nauczyło się na lekcji pisania CV, aż 37\% zyskało tę umiejętność na własną rękę. Jedynie $31 \%$ poznało w szkole zasady uczestnictwa w rozmowie kwalifikacyjnej. 
Ocena nauczycieli przez uczniów była, jak widać, surowa, choć niejednoznaczna. Nauczyciele wydają się sprawnymi profesjonalistami (potrafią zachować dyscyplinę, znają atrakcyjne metody dydaktyczne), ale nie są porywający, nie zarażają entuzjazmem, rzadko bywają nowocześni, w małym stopniu motywują uczniów do zainteresowania przedmiotem, nie poświęcają swoim wychowankom wystarczająco dużo uwagi.

\section{Uczniowie w Szkole ${ }^{12}$}

Polskim piętnastolatkom szkoła jawiła się jako wymagająca, ale mało atrakcyjna. Ciężar wysiłku, w ich opinii, został przerzucony na nich samych. Po części wynikało to z atmosfery szkolnej, w której większą rolę odgrywała rywalizacja niż współpraca, zresztą pod tym względem jesteśmy krajem zupełnie przeciętnym w porównaniu z pozostałymi krajami OECD. Polscy uczniowie, podobnie jak ich koledzy gdzie indziej, nie narzekali na tę sytuację, wykazywali się ambicją, żeby wykonywać zadania lepiej niż inni. Pod niektórymi względami jednak trochę odstawali: mimo wszystko rzadziej się starali w warunkach rywalizacji, byli mniej wytrwali niż ich koledzy w innych krajach. Równocześnie jednak odczuwali silną motywację zewnętrzną w swoich wysiłkach: znacznie częściej niż uczniowie gdzie indziej wyrażali przekonanie, że ciężka praca w szkole pomoże im w dostaniu się na dobrą uczelnię, zrobienie kariery zawodowej czy po prostu że ciężka praca jest ważna. Zarazem - co w tym kontekście może się wydać dziwne - mieli trochę mniejsze niż gdzie indziej poczucie własnej sprawczości.

Do surowej oceny polskiej szkoły dochodzi kwestia panującego w niej klimatu. Uczniowie w zbyt małym stopniu znajdowali oparcie w nauczycielach, a zarazem bywali narażeni na złe traktowanie przez kolegów. Częściej niż gdzie indziej zdarzały się przypadki dręczenia. O ile uporczywe (przynajmniej kilka razy w miesiącu) dręczenie było na poziomie przeciętnym dla OECD (tylko w... plotkowaniu negatywnie odstajemy od reszty, doświadcza tego $40 \%$ młodych ludzi, z tego 15\% bardzo często, w OECD 29\%, w tym często $11 \%$ ), o tyle okazjonalne akty przemocy dotykały większości uczniów (w OECD 48\% piętnastolatków nigdy nie doświadcza dręczenia, w Polsce 43\%). Jeszcze bardziej musi niepokoić podejście uczniów do dręczenia. Pod tym względem możemy mówić o porażce wychowawczej. Otóż polscy uczniowie zdecydowanie rzadziej niż ich koledzy w innych krajach wykazywali się negatywnym podejściem do przemocy. Oto przykłady, odpowiedzi „zdecydowanie tak”: denerwuje mnie, gdy nikt nie broni uczniów nękanych przez rówieśników - Polska 26\%, OECD 34\%; to dobrze, gdy pomaga się uczniom, którzy nie potrafią się obronić - Polska 26\%, OECD 36\%; to źle, gdy samemu się dołącza do grupy, która nęka innych - Polska 30\%, OECD 52\%; czuję się źle, gdy widzę, jak inni uczniowie są nękani przez rówieśników - Polska 26\%, OECD 42\%; podoba mi się, gdy ktoś staje w obronie

12 Por. Krzysztof Bulkowski, Michał Sitek, Komponent kwestionariuszowy badania PISA: dobrostan uczniów i klimat szkoły, w: Sitek, Ostrowska 2020, 236-253. 
uczniów nękanych przez rówieśników - Polska 31\%, OECD 46\%. Te dane powinny być powodem do rachunku sumienia dla rodziców i nauczycieli, w tym szczególnie polonistów, którzy przecież na lekcjach podejmują zagadnienia etyczne. Co dopiero mówić o nauczycielach etyki i katechetach.

Nie ma się co dziwić, że w tej sytuacji znajdujemy dużą grupę młodzieży, która w polskiej szkole czuje się źle. 19\% odpowiadających uczniów deklarowało osamotnienie w szkole (OECD 16\%), 23\% twierdziło, że nie pasuje do szkoły (OECD 20\%), 40\% sądziło, że nie jest częścią szkoły (OECD 29\%), 27 \% uważało, że nie są lubiani (OECD 19\%). Wszystkie te wskaźniki znacznie się pogorszyły między rokiem 2012 a 2018. Sześć lat wcześniej 9\% uczniów odczuwało osamotnienie w szkole, $11 \%$ odpowiadało, że nie pasuje do szkoły, $16 \%$ czuło, że nie są lubiani. Nie ma się wobec tego co dziwić, że spora część uczniów opisuje swoje emocje jako smutek, niedostatek wesołości, bark poczucia dumy, a nawet strach i przerażenie. Mało tego. 34\% piętnastolatków uważa, że ich życie nie ma sensu i celu (OECD 32\%), 44\% dotychczas nie odnalazło sensu życia (OECD 38\%). Dodajmy, że negatywne emocje dominują wśród dziewcząt. Tylko $54 \%$ z nich wyraża zadowolenie z życia (OECD 61\%), chłopcy są zadowoleni z życia w 70\% (OECD 72\%).

\section{Wnioski}

Badanie PISA przynosi bardzo dużo informacji o piętnastolatkach, ale też o szkole, a może nawet - przy ostrożnym wnioskowaniu - całym społeczeństwie. Entuzjastyczne tytuły mówiące o sukcesie mają odzwierciedlenie w faktach. Ma też takie pokrycie alarm, że coś złego się dzieje z dobrostanem młodych ludzi w Polsce. Nie ma tu sprzeczności, prawda - jak widać - jest skomplikowana. Bardzo łatwo te dane przykrawać do tez ideologicznych, politycznych czy publicystycznych. Zwłaszcza gdy potraktuje się je bez koniecznej analizy, wykorzystując same liczby i szukając dowodów na gotowe opinie. Właściwie można by przeprowadzić osobne badanie nad recepcją wyników PISA. Ile w ich wykorzystywaniu niedoczytania, niezrozumienia, nadmiaru emocji, a czasem złej woli.

Od razu podkreślmy: badanie dotyczyło przedostatniego rocznika likwidowanego gimnazjum. To stawało się powodem rozbieżnych opinii. Bo przecież doskonałe wyniki świadczyły o tym, że ten model szkoły się sprawdził i nie należało go unicestwiać. Obrońcy reformy wszakże mogli dowodzić, że osiągnięcia uczniów są niezależne od istnienia lub nieistnienia gimnazjum, system szkolnictwa nie ma tu nic do rzeczy. Były też głosy, że to nie szkoła pomogła młodym ludziom, ale wykazali się oni tym, czego sami niezależnie się nauczyli. Wyniki ankiet nie tylko nie osłabiły poszczególnych poglądów, ale je nawet wzmocniły. Zwolennicy likwidacji gimnazjów znaleźli argumenty za tym, że tamta forma szkoły była powodem poczucia nieszczęścia uczniów i trzeba było szybko to zmienić, żeby ich wyzwolić ze stresu, strachu i doznawania przemocy. Obrońcy status quo ante podkreślali, iż 
problem jest znacznie głębszy i nie dotyczy systemu szkolnictwa, lecz ogólnej filozofii stojącej u podstaw polskiej edukacji, w której nie zwraca się uwagi na dobrostan uczniów.

Ponieważ w interpretacji danych, jak w każdej interpretacji, ogromną rolę odgrywa nastawienie interpretatora, nie pogodzimy rozbieżnych stanowisk na temat edukacji, które oparte są na tych samych wynikach badania. Spróbujmy zatem zaproponować własną interpretację.

Niewątpliwie polska szkoła - $\mathrm{w}$ tej formie, jaką miała przed reformą - była skuteczna w kształceniu tych umiejętności, które bada PISA. To jej siła, bo nie chodzi przecież o dostosowanie się do wymogów badania, ale o wyposażenie młodych ludzi w kluczowe kompetencje niezbędne w dorosłym życiu. Od razu jednak podkreślmy czas przeszły. Mowa o skuteczności nauczania w zlikwidowanych właśnie gimnazjach. O tym, czy efekty będą równie imponujące $\mathrm{w}$ szkołach podstawowych, na razie nie możemy nic powiedzieć. Wyniki egzaminów ósmoklasisty przekazują zupełnie inne informacje niż PISA, więc nie można ich porównywać $\mathrm{z}$ wynikami tego badania. Inna sprawa, że zadania na egzaminach w pewnej mierze konstruowane są podobnie jak zadania w badaniach międzynarodowych, bo takie są współczesne standardy tworzenia testów.

Równocześnie badanie pokazuje cenę, jaką polscy uczniowie zapłacili za sukces, a w istocie pole dużego zaniedbania w pracy wychowawczej. Co prawda nie wiemy, czy surowa ocena nauczycieli i w ogóle klimatu szkoły w badaniu 2018 nie zostały w jakiejś mierze zdeformowane przez fakt, że było ono prowadzone w gimnazjach w stanie likwidacji, więc uczniom mogła się udzielić nerwowa atmosfera. To jednak nie zmienia faktu, że duża część uczniów czuła się zaniedbana przez swoich nauczycieli. To powodowało nie tylko to, że nie dostawali informacji zwrotnej o swoich mocnych i słabych stronach (zwłaszcza tych pierwszych), ale pozostawieni byli sami sobie wobec agresji i nękania ze strony rówieśników. Nie czuli się dobrze w szkole, a nawet poza nią (stosunkowo niskie wskaźniki radości i szczęścia, a wysokie smutku). Uderzający jest ich pesymizm w stosunku do siebie i do możliwości reagowania na zło. Pod względem wychowawczym polska szkoła okazała się nad wyraz bezradna. Czy po reformie będzie bardziej przyjazna wobec uczniów i skuteczniejsza również w przekazywaniu wartości? Deklaracje zawarte w podstawach programowych i deklaracjach władz edukacyjnych wskazywały, że tak. Oby one przekuły się w rzeczywistość. Niestety, skoro na pierwszym miejscu stawiane są wartości patriotyczne i ogólnie zbiorowe, z pola widzenia mogą zniknąć konkretne problemy poszczególnych uczniów. Zresztą nie jest to tylko przypuszczenie. Obserwacje szkoły po reformie wskazują, że program wychowawczy w dużej mierze wyczerpuje się w deklaracjach i obrzędach, na wpajanie wartości etycznych zazwyczaj brakuje czasu, umiejętności, a nawet niekiedy woli.

Warto na informacje, które przynosi nam PISA, spojrzeć również z perspektywy doświadczenia szkoły w dobie pandemii. Przejście do nauczania 
online było powodem wielu kłopotów, choć przecież mogło też stanowić szansę. Badanie pokazało, że uczniowie dobrze sobie radzili z lekturą tekstów, które znajdują w sieci. Chyba jednak ich umiejętności tylko częściowo były kształtowane przez szkołę. To znaczy: niewątpliwie szkoła uczy uważnej lektury, ale nie na przykładzie internetowych hipertekstów. Pamiętamy, że w gimnazjum tylko połowa nauczycieli korzystała na lekcjach z elektronicznych środków przekazu. W szkołach podstawowych czy średnich po reformie, a przed pandemią, pewnie było podobnie. Nie dziwmy się zatem, nowa sytuacja stanowiła dla nauczycieli nie lada wyzwanie. Po drugiej stronie problemem był dostęp uczniów do odpowiedniego oprzyrządowania. Co prawda prawie wszyscy deklarowali posiadanie komputera, ale - jak zauważyliśmy wcześniej - nic nie wiemy o tym, czy każde dziecko w rodzinie miało swój własny komputer, czy miało pokój, w którym mogłoby spokojnie uczestniczyć w lekcji online, czy wszyscy dysponowali dostępem do łączy internetowych itd.. To są wyraźne bariery w prowadzeniu zdalnego nauczania w Polsce, których nie można lekceważyć. Z drugiej jednak strony można mówić o szansie, gdyż nowe warunki spowodowały, że trzeba było odświeżyć metody dydaktyczne, wyjść poza rutynę, nawiązać - paradoksalnie - bliższy kontakt z uczniem, zacząć intensywniej korzystać z sieci. Te negatywne zjawiska, które PISA wydobyła na światło dzienne, można było w tej nadzwyczajnej sytuacji skorygować. To jednak tylko szanse. Czy zostały wykorzystane? Na to pytanie mogą dać odpowiedź kolejne badania. Na pewno jednak nie ma powrotu do szkoły sprzed pandemii. Dlatego konieczne jest zmierzenie się z kilkoma bardzo poważnymi problemami: od infrastruktury technicznej przez nowe kompetencje nauczycieli po korektę podstaw programowych, które w dużej mierze nie przystają do nowej sytuacji - na przykład na lekcjach języka polskiego trzeba inaczej traktować tekst, w nietradycyjny sposób postrzegać sytuację czytelnika, uwzględniać konteksty technologiczne, kulturowe i psychologiczne, które radykalnie zmieniają styl lektury.

Wnioski z wyników badania PISA są wyraźne. Róbmy wszystko, żeby nie zaprzepaścić tego, że nauczyliśmy się wyposażać uczniów w umiejętności uważnej lektury, samodzielnego myślenia, rozwiązywania problemów naukowych, rozumienia i rozumowania. To kapitał, którego nie możemy roztrwonić. Zarazem podejmijmy intensywną refleksję, co zrobić, żeby poprawić dobrostan młodych ludzi, nie zostawiać ich samych z kłopotami, uwrażliwiać na zło, które dostrzegają wokół siebie. I żeby odważniej wykorzystywać elektroniczne formy przekazywania myśli.

Na koniec jeszcze jedna refleksja. Wśród zadań w badaniu PISA niektóre dotyczyły umiejętności sprawdzania informacji, ich weryfikowania, oceniania wiarygodności. Polscy uczniowie całkiem dobrze sobie z nimi poradzili. Warto, by tymi umiejętnościami potrafili się posługiwać również ci, którzy komentują wyniki PISA, a także wykorzystują je w podejmowaniu decyzji dotyczących szkoły. Jak w badaniu: najpierw trzeba uważnie 
przeczytać, potem zrozumieć, wreszcie na drodze precyzyjnego rozumowania wyciągać wnioski i je uzasadniać.

\section{Bibliografia}

PISA 2018. Assessment and Analytical Framework, https://www.oecd-ilibrary. org/docserver/b25efab8-en.f?expires $=1601304757 \&$ id =id\&accname $=$ guest \&checksum =B9381EED5E1B07253EEB8FF0D93FB7AA (dostęp 8.10.2020)

Sitek Michał, Ostrowska Elżbieta Barbara (red.), 2020, PISA 2018. Czytanie, rozumienie, rozumowanie, Warszawa.

Zasacka Zofia, 2019, Czytelnictwo młodziė̇y szkolnej 2017, „Rocznik Biblioteki Narodowej", Warszawa.

\section{O Autorze}

Krzysztof Biedrzycki - dr hab., profesor nadzwyczajny w Katedrze Krytyki Współczesnej na Wydziale Polonistyki Uniwersytetu Jagiellońskiego, prof. nadzwyczajny w Instytucie Badań Edukacyjnych w Warszawie. Krytyk literacki i filmowy. Zajmuje się głównie współczesną poezją polską, jakkolwiek jego zainteresowania są szersze i obejmują teorię oraz praktykę interpretacyjną obejmującą literaturę i film różnych epok. Brał udział w badaniach życia literackiego międzywojennego Wilna. Jest badaczem edukacji, teoretykiem procesu dydaktycznego i twórcą narzędzi dydaktycznych do nauczania języka polskiego w szkole. Wykładał na uczelniach zagranicznych: visiting professor na uniwersytetach amerykańskich: University of Rochester (1996) i Central Connecticut State University (2001), lektor języka polskiego na Université de Borgogne oraz nauczyciel języka polskiego w liceum w Dijon we Francji (1997-1999), prowadził pojedyncze wykłady na kilku uniwersytetach zagranicznych (m.in. Harvard University, Paris IV La Sorbonne, Uniwersytet Wileński i Uniwersytet Pedagogiczny w Wilnie). Członek redakcji pisma "NaGłos” w latach 1990 - 1997 oraz pism „Edukacja” (od 2011 do 2018) i „Polonistyka. Innowacje” (od 2015).

Przewodniczący Rady Konsultacyjnej Ośrodka Badań Literatury Dziecięcej i Młodzieżowej na Wydziale Polonistyki UJ oraz członek Rady Centrum Badań Edukacyjnych i Kształcenia Ustawicznego na Wydziale Polonistyki UJ.

Na Wydziale Polonistyki prowadzi zajęcia z literatury po 1989 roku oraz warsztaty krytyczne. 